V.S. Petrushin

\title{
METHODICS, SOFTWARE AND LABORATORY EQUIPMENT FOR AN INNOVATIVE ELECTRICAL ENGINEERING DISCIPLINE
}

\begin{abstract}
Purpose. Development of innovative electrical engineering discipline «Electric Machines in Mechatronic Systems» in order to improve the training of specialists of electrical engineering specialty. Methodology. The proposed project concerns the educational reforms that promote the intensification of the educational process. Results. The structure of interactive educational and training complex, which is a computer learning tool in the form of software and methodical support, as well as data and knowledge bases and consists of functionally related multimedia learning systems, interactive learning, automated control of the learning process. Originality. To offer online training and research facilities, guidelines for laboratory and computational and graphic works. Practical value. Increase the knowledge of students of educational material related to the discipline of innovation "Electric Machines in Mechatronic Systems». References 11.
\end{abstract}

Key words: innovative electrical engineering discipline, sections of the academic discipline, guidelines for calculation and graphic works.

Предлагается инновационная электротехническая дисциплина «Электрические машины в мехатронных системах». Обосновывается необходимость изучения дисциплины студентами электротехнической специальности. Приведены разделы и объем дисциплины, а также методическое, программное и лабораторное обеспечение, способствующее качественному усвоению учебного материала. Перечислены разработанные мероприятия и методические указания к расчетно-графическим работам данной дисциплине. Библ. 11.

Ключевые слова: инновационная электротехническая дисциплина, разделы учебной дисциплины, методические указания к расчетно-графическим работам.

Currently the educational process concerning the majority of technical disciplines, including electrical engineering, is not keeping pace with the rapid development of the industry. To overcome this drawback, it is advisable to introduction into the educational process of topical subjects, most meet the needs of today, in particular the discipline «Electric Machines in Mechatronic Systems». Sections of discipline are: semiconductor converters of mechatronic systems; features of the induction motors in adjustable electric drives, valve drives, design of regulated induction and brushless motors, DC motors work in regulated electric drives, transformers for mechatronic systems, especially of synchronous generators to the converter load.

The use of variable speed drives (VSD) which are the basis of modern high technology in all sectors of industry and transport makes it possible to improve the manufacturing processes, provides comprehensive mechanization and automation of production, enhances the quality of products, reduce its production costs, increase productivity, improve the reliability and life of the equipment. Widespread use has led to VSD what a modern electric drive is not only energy-power basis capable of supporting production mechanisms necessary mechanical energy, but also a means of process control as well as tasks for the implementation of the quality of production processes currently in the majority of cases are assigned to the adjustable control system ac- tuators in conjunction with systems technological automation. Of particular importance is the use of energy-saving aspects of the VSD. In connection with the increase in energy prices, in particular for electricity, and limited increase in power generating capacity problem of energy saving systems, including the reduction of power consumption, it is of particular relevance. Energy conservation has become one of the priority directions of technical policy in all developed countries. This is due, firstly, to the limited and non-renewable primary energy, and secondly, with the continuously increasing complexity of production and the value in the third to global environmental problems.

Electromechanical systems with adjustable induction (IM) and electronic (EM) motors in which the union of energy and information processes takes place, ensure maximum use of the opportunities and achievements of electronics for converting electrical energy into mechanical energy. This is achieved by increasing the service life of equipment, reducing operating losses, high reliability.

Insufficient knowledge of the operation of the main unit controlled electric drive - IM or EM - does not allow the drive to improve due to the modernization of this link. A comprehensive analysis of IM and EM in VSD systems based on a systems approach and systems analysis methods makes it possible to design a special adjustable IM and EM with improved adjusting, launchers, dynamic and 
vibroacoustic performance, reduced mass, size and cost characteristics. The demand for professionals possessing knowledge gained in the process of studying the discipline is observed in all areas of industry and transport, which are used electromechanical energy conversion devices. Particular influence is expected in the electrical industry, engaged in the design and manufacture of motors under consideration [1].

The proposed project concerns the educational reforms that promote the intensification of the educational process, in terms of the development of courses for a bachelor's degree. Academic discipline «Electric Machines in Mechatronic Systems» can be introduced into the educational process on the basis of the principles stipulated by the European Credit Transfer System (ECTS). Formation of individual student's educational plan provides a choice of this discipline, respectively structural and logical scheme of training. Workload in the discipline of four ECTS credits in one semester. It provides 30 hours of lectures, 15 hours of laboratory exercises. In the process of studying this discipline students perform independent course work. Control of Learning is carried out with the use of modern methods and techniques and recorded estimates ECTS scale. The discipline can be taught in the traditional mode and in remote mode.

Modern teaching techniques should be adapted to the new principles of the organization of educational process is provided by the introduction of the industry has problems raising the level of preparation of students to engineering. Fixed assets should include measures for the development and implementation of information technology education, the development of research and scientific and technological activities in the education system. Innovative engineering discipline should be provided with modern methodological and software development, allowing not only the conduct of full-time, but also in absentia, remote, post-graduate training. Using the European educational trends in Ukraine will bring the national standards of teaching to the standards of European education. One result is the establishment of a working relationship between the training activities, scientific research, production and social practice.

To solve the above was carried out as follows:

- satisfied formation (development) of innovative technical discipline, training material that is the most relevant topics, and that topicality confirmed the latest developments in the electrical industry. The relevance of the discipline «Electric Motors in Mechatronic Systems» supported by the extensive use of VSD in all branches of industry and transport for sustainable management process while minimizing energy consumption;

- carried out the development of the structure of interactive educational and training complex for this innova- tive discipline, which is a computer learning tool in the form of software and methodical support, as well as data and knowledge bases and consists of functionally related multimedia learning systems, interactive learning, automated control of the learning process;

- made the development of multimedia teaching system comprising electronic textbooks and teaching aids for the course in the form of media, as well as various manuals;

- carried out the development of interactive learning system, which is a computer simulator, with which you can perform a number of settlement-graphic (analysis of the serial general-purpose IM in different systems of VSD, designing special controlled IM and EM to work in VSD) and virtual labs for study It features the work of IM and IM in different systems of VSD. To perform an interactive learning system developed by multi-level software, allows the analysis of electromagnetic electromechanical, power, thermal, mechanical, vibro-acoustic processes in the engine and on the basis of this analysis, to carry out an automated selection and design optimization motors of VSD. The opportunity of communication developed software with other commonly used in the industry and computing facilities;

- made the development of an automated control system, which serves for the input, current and final control, and includes testing programs, a database of test questions and answers, registration and accounting log, temporary training statistics in graphic form;

- providing support to developing individual educational trajectories, using the system, open and distance education in remote access via the global Internet network, which has interactive and differentiated approach to learning;

- quality education is possible by this innovative technology discipline everyone access to all comers methodical and program materials;

- possible formation of an active dialogue between the users in the study of this discipline and communities with an interest in this technical discipline;

- data can be provided and the sharing of knowledge required for new educational and research approaches for the presentation and dissemination of results, preparation of research presentations.

Computer code DIMAS-Drive [2] performs mathematical modeling of physical (electromagnetic, electromechanical, thermal, mechanical, vibro-acoustic) processes in static and dynamic modes of induction motors, regulated electric drives with matching transformers and gearboxes, with semiconductor converters, different types, species and management methods, frequency control laws. Mathematical models take into account the structural features of the motors (closed and secure ver- 
sion) and cooling (self-cooling and independent cooling, ventilation ducts), squirrel cage design. Taken into account the impact on the physical processes of magnetic circuit saturation, displacement currents in the windings, the presence of the highest space-time harmonics. We consider the mechanical and vibro-acoustic performance in dynamic conditions. On the basis of multiple targeted simulation taking into account the nature, size and mode of operation of load in a certain range of control is carried out design (structural and parametric optimization) special controlled asynchronous motors with different formulations of the problems (designing a predetermined control range, design, taking into account the duration of the work on specific speeds, projecting a predetermined tachogram considering transitions).

Developed guidelines [3-11]: for laboratory work on the experimental stands or virtual laboratory works; to the settlement and graphic works: a study of electromechanical and power characteristics of the controlled induction motors; analysis of the thermal state of the controlled induction motors; analysis of the vibro-acoustic performance of controlled induction motors; Study the performance of electric rolling stock traction with induction motors; analysis of electronic motors.

Performing by students laboratory work on experimental stands or virtual labs to study the characteristics of motors and drives at the phase and frequency control makes it possible to fix in practice theoretical principles.

The knowledge gained as a result of studying the discipline «Electric Machines in Mechatronic Systems» can be used when the final works on the Bachelor and Master levels.

Implementation of a large number of educational projects (traction induction motors of electric locomotives and urban electric transport, motors of pumping and ventilation systems controlled performance, conveyors and transporters, roller conveyors, geared and gearless elevator winches, etc.) showed that as a result of the design could reduce the power required frequency converters and reduce the size of motors at constant capacity or increase their power at constant dimensions in agreement converter settings and design motors for these settings.

\section{REFERENCES}

1. Petrushin V.S. Asinhronnye dvigateli v reguliruemom elektroprivode: Uchebnoe posobie [Induction motors in adjustable electric: Textbook]. Odessa, Nauka i tehnika Publ., 2006. 320 p. (Rus). Available

at: https://books.google.com/books?isbn=966833549x.

2. Petrushin V.S., Rjabinin S.V., Yakimets, A.M. Programmnyj produkt «DIMASDrive». Programma analiza raboty, vybora i proektirovanija asinhronnyh korotkozamknutyh dvigatelej sistem reguliruemogo elektroprivoda [Program performance analysis, selection and design of asynchronous cage motors controlled drive systems]. Patent UA, no.4065. (Ukr).
3. Petrushin V.S., Yakimets, A.M. Metodichni vkazivki do rozrakhunkovo-grafichnoï roboti $z$ distsiplini «Elektrichni mashini v regul'ovanomu privodi» dlia studentiv napriamku «Elektromekhaniki» [Guidance for calculation-graphic work on the subject «Electric machines in a regulated drive» for students of direction «Electromechanics»]. Odesa, ONPU Publ., 2007. 33 p. (Ukr). Available at: http://memos.library.opu.ua:8080/memos/jsp/materials.iface? $\mathrm{mId}=7556$.

4. Petrushin V.S., Yakimets A.M., Lysenko S.I. Metodichni vkazivki do rozrakhunkovo-grafichnoï roboti z distsiplini «Elektromekhanotronika» [Guidance for calculation-graphic work on the subject «Elektromehanotronika»]. Odesa, ONPU Publ., 2008. 13 p. (Ukr). Available at: http://memos.library.opu.ua:8080/memos/jsp/materials.iface?mI $\mathrm{d}=10594$.

5. Petrushin V.S., Yakimets A.M., Grusha A.V. Metodichni vkazivki do laboratornikh robit $z$ doslidzhennia kharakteristik asinkhronnikh dviguniv pri fazovomu ta chastotnomu reguliuvanniakh $z$ distsiplini «Elektrichni mashini $v$ regul'ovanomu privodi» dlia spetsialistiv i magistriv za fakhom «Elektrichni mashini ta aparati» ta «Elektrichnii transport» [Guidance for laboratory works on research performance phase asynchronous motors with frequency regulation and discipline «Electric machines in a regulated drive " for specialists and masters in the specialty «Electrical machines and apparatus « and «Electric transport»]. Odesa, ONPU, Publ., 2008. 34 p. (Ukr). Available at: http://memos.library.opu.ua:8080/memos/jsp/materials.iface? mId $=11945$.

6. Petrushin V.S., Yakimets A.M., Barbiniagra M.P. Metodichni vkazivki do laboratornikh robit $z$ doslidzhennia teplovikh kharakteristik asinkhronnikh dviguniv z distsiplini «Teplovi ta ventiliatsiini rozrakhunki elektrichnikh mashin» dlia spetsialistiv i magistriv za fakhom «Elektrichni mashini ta aparati» ta «Elektrichnii transport» [Guidance for laboratory works on the study of thermal characteristics of asynchronous motors with the subject «Heating and ventilation calculations electric machines» for specialists and masters in specialty «Electrical machines and apparatus» and «Electric Transport»]. Odesa, ONPU Publ., 2011. 28 p. (Ukr). Available at: http://memos.library.opu.ua:8080/memos/jsp/materials.iface?mI $\mathrm{d}=15442$.

7. Petrushin V.S., Yakimets A.M. Metodichni vkazivki do laboratornikh robit $z$ doslidzhennia kharakteristik asinkhronnikh dviguniv pri zhivlenni vid chastotnogo peretvoriuvacha $z$ riznimi nalashtuvanniami z distsiplini «Elektromekhanotronika» dlia magistriv za fakhom «Elektrichni mashini ta aparati» ta «Elektrichnii transport» [Guidance for laboratory works on research performance asynchronous motors with power from the frequency converter with different settings on discipline «Elektromehanotronika» for masters in specialty «Electrical machines and apparatus» and «Electric Transport»]. Odesa, ONPU Publ., 2011. 25 p. (Ukr). Available at: http://memos.library.opu.ua:8080/memos/jsp/materials.iface?mI $\mathrm{d}=15445$.

8. Petrushin V.S., Yakimets A.M., Pirkovs'kii S.M. Metodichni vkazivki do rozrakhunkovo-grafichnoï roboti z distsiplini «Osnovi elektrichnoï tiagi» dlia studentiv napriamku «Elektromekhaniki» [Guidance for calculation-graphic work on the subject 
«Fundamentals of electric traction» for students of direction «Electromechanics»]. Odesa, ONPU Publ., 2012. 36 p. (Ukr). Available at:

http://memos.library.opu.ua:8080/memos/jsp/materials.iface?mI $\mathrm{d}=17537$.

9. Petrushin V.S. Metodichni vkazivki do rozrakhunkovografichnoï roboti z distsiplini «Vibratsiia ta shum elektrichnikh mashin» dlia studentiv napriamku «Elektromekhaniki» [Guidance for calculation-graphic work on the subject «The vibration and noise of electrical machines» for students of direction «Electromechanics»]. Odesa, ONPU Publ., 2015. 27 p. (Ukr). Available

http://memos.library.opu.ua:8080/memos/jsp/materials.iface?mI $\mathrm{d}=25120$.

10. Rymsha V.V., Yakimets A.M. Modeliuvannia ventil'noreaktivnikh dviguniv. Doslidzhennia kharakteristik. Metodichni vkazivki do vikonannia rozrakhunkovo-grafichnoï roboti pri pidgotovtsi fakhivtsiv za napriamkom 0922 - «Elektromekhanika» [Simulation of valve-jet engines. Research characteristics. Guidance for calculation-graphic work at the direction of training 0922 - «Electromechanics»]. Odesa, ONPU Publ., 2006. 26 p. (Ukr). Available at: http://memos.library.opu.ua:8080/memos/jsp/materials.iface?mI $\mathrm{d}=6923$.

How to cite this article:

Petrushin V.S. Methodics, software and laboratory equipment for an innovative electrical engineering discipline. Electrical engineering \& electromechanics, 2016, no.4, pp. 69-72. doi: 10.20998/2074-272X.2016.4.10.
11. Petrushin V.S. Metodichni vkazivki do virtual'nikh laboratornikh robit $z$ doslidzhennia kharakteristik asinkhronnikh dviguniv pri fazovomu ta chastotnomu reguliuvanniakh $z$ distsiplini «Elektrichni mashini $v$ regul'ovanomu privodi» dlia spetsialistiv i magistriv za fakhom "Elektrichni mashini ta aparati» ta «Elektrichnii transport» [Guidance for virtual lab works on research performance phase asynchronous motors with frequency regulation and discipline «Electric cars drive in a regulated» for specialists and masters in «Electrical machines and apparatus» and «Electric Transport»]. Odesa, ONPU Publ., 2016. 19 p. (Ukr). Available at: http://memos.library.opu.ua:8080/memos/jsp/ materials.iface $? \mathrm{mId}=26860$.

Received 17.03.2016

V.S. Petrushin, Doctor of Technical Science, Professor, Odessa National Polytechnic University, 1, Shevchenko Avenue, Odessa, 65044, Ukraine. phone +380048 7058494, e-mail: victor_petrushin@ukr.net 


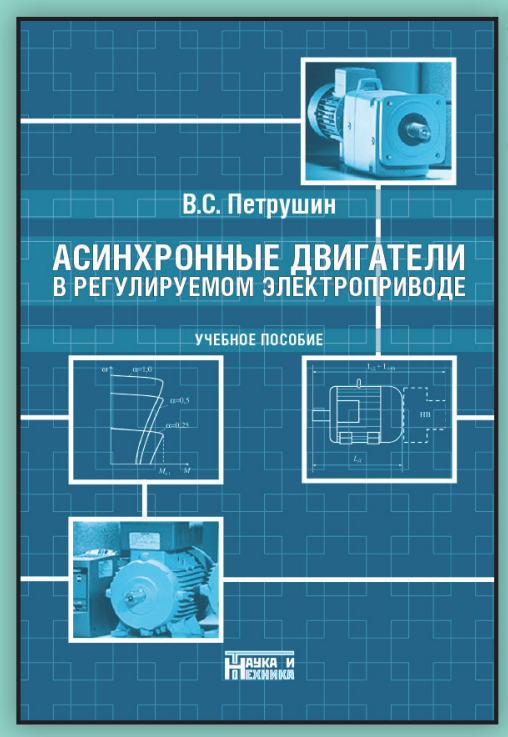

semiconductor converters

operation induction motors the adjustable

electric drive

brushless motor

design asynchronous induction and brushless

motors in adjustable-speed electric drive

operation dc motors the adjustable electric drive

transformers for installations with semiconductor converters

features of synchronous generator on the converter load

Guidelines:

- To laboratory works on experimental stands;

Virtual laboratory works.

Settlement and graphic works:

- Study of electromechanical and power characteristics of the controlled induction motors;

Analysis of the thermal state of the controlled induction motors;

Analysis of the vibro-acoustic performance of controlled asynchronous motors;

Study of the performance of electric rolling stock

traction with asynchronous motors;

Analysis of the valve-jet engines.

\section{Innovative Electrical discipline "Electric machines in mechatronic systems" laboratory software}
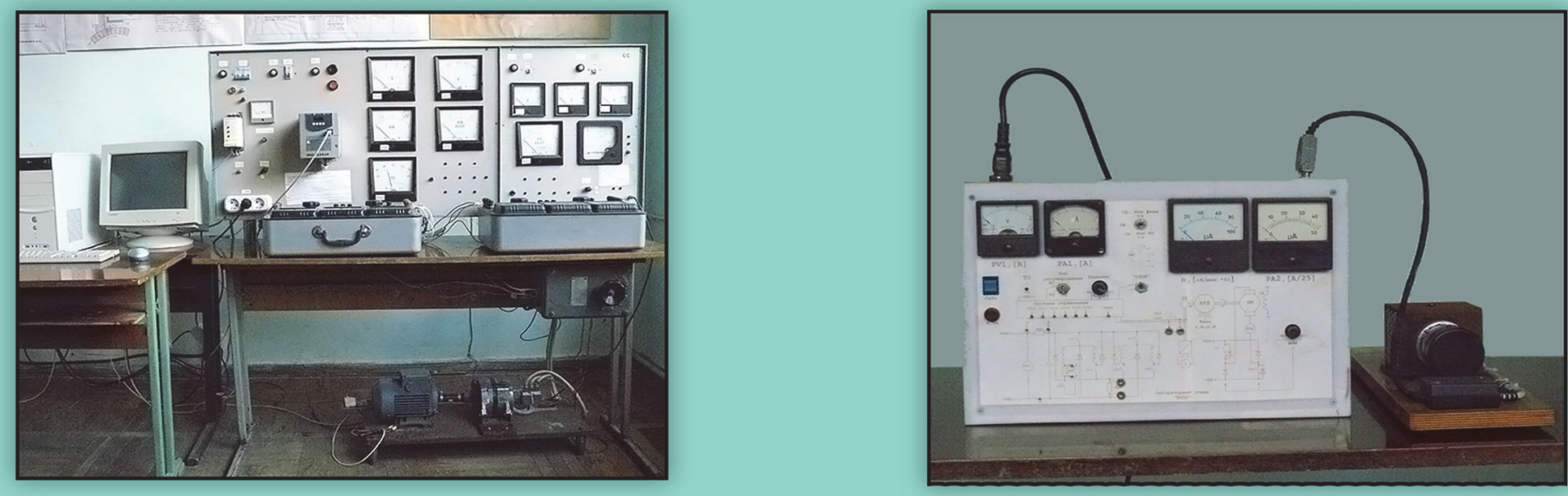

\section{program software}
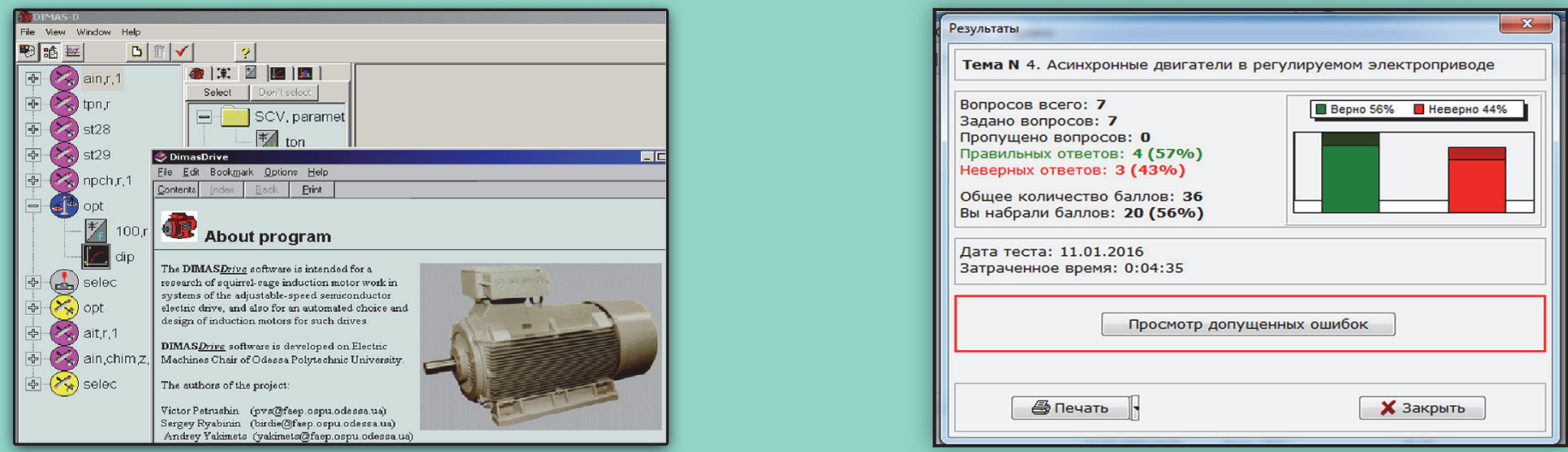

\section{Simulation of steady-state and dynamic modes}

\begin{tabular}{|l|l|}
\hline $\begin{array}{c}\text { Electromagnetic and } \\
\text { electromechanical } \\
\text { processes }\end{array}$ & $\begin{array}{l}\text {-Accounting for saturation and displacement } \\
\text {-Accounting for higher space-time harmonics (HSTH) }\end{array}$ \\
\hline Energy processes & $\begin{array}{l}\text {-Accounting for the additional losses from electrical HSTH } \\
\text {-Accounting for magnetic additional losses }\end{array}$ \\
\hline Thermal Processes & $\begin{array}{l}\text {-Accounting for variable thermal conductivities } \\
\text {-Accounting for additional electrical and magnetic losses } \\
\text {-Accounting for mechanical heating losses }\end{array}$ \\
\hline
\end{tabular}

\begin{tabular}{|c|c|}
\hline Vibroacoustic processes & $\begin{array}{l}\text { - NVH performance magnetic nature } \\
\text { - NVH performance of the mechanical nature } \\
\text { - Ventilation noise }\end{array}$ \\
\hline $\begin{array}{l}\text { Calculations of the } \\
\text { mechanical parameters }\end{array}$ & $\begin{array}{l}\text { - Shaft deflection } \\
\text { - The critical speed } \\
\text { - Mechanical stress } \\
- \text { Dynamic load bearing }\end{array}$ \\
\hline $\begin{array}{l}\text { Calculations of the } \\
\text { parameters of mechanical } \\
\text { characteristics }\end{array}$ & $\begin{array}{l}\text { - Overload capability } \\
\text { - Mechanical stiffness characteristics }\end{array}$ \\
\hline
\end{tabular}

